\title{
SPIDERS LIVING AT WASP NESTING SITES: WHAT CONSTRAINS PREDATION BY MUD-DAUBERS?
}

\author{
By Martin S. Obin ${ }^{1}$
}

The nests of mud-daubing wasps (Hymenoptera: Sphecidae) are excellent sources of spiders (Peckham and Peckham, 1898; Rau, 1935; Muma and Jeffers, 1945; Dorris, 1970). Females of these solitary wasp species construct mud nests during the late spring and summer. They provision each brood cell with a number of spiders which they capture and paralyze by stinging. The wasp lays an egg on one of these spiders and, upon hatching, the larva consumes all the spiders within the brood cell. When development is complete, the new adult wasp chews a hole in its brood cell and emerges. A cell in the nest of mud-daubers such as Sceliphron caementarium or Chalybion californicum may contain in excess of 25 spiders. It seems likely then that mud-dauber predation may be a significant factor influencing population dynamics and evolution of those spider genera taken as prey (see also Eberhard, 1970). But this view of wasp and spider interactions is incomplete. The same sites at which mud-daubers nest are also used by both wandering and webbuilding spiders for capturing prey and tending eggs. Mud-dauber nests themselves are often used by spiders for these activities. In fact, among the group of spiders active at mud-dauber nesting sites are species that are regularly taken as prey by those same spiderhunting wasps. Intrigued by this fact, I initiated field studies that addressed the following questions:

1. What groups of spiders are found living at nesting sites of mud-daubers?

2. What is the nature of the interactions between wasps and spiders at these sites?

3. If wasps do not hunt spiders at nesting sites, what factors constrain them from doing so?

'Department of Zoology, University of Florida, Gainesville, FL 32611

*Manuscript received by the editor July 25, 1982. 


\section{Materials and Methods}

Procedure. Nesting sites and mud nests of three species of sphecid wasp were observed during the summer of 1980. Three groups of spiders were collected. These were: (a) active spiders within 2 meters of wasp nesting sites, (b) active spiders on or next to mud-dauber nests, and (c) paralyzed spiders from inside 110 old nests. Spiders were identified and their total body lengths measured. No attempt was made to census every spider at each site, as this would have proven impossible for genera such as Tidarren and Filistata which were numerous, mobile and often reclusive. In addition, encounters between spiders and wasps were observed and recorded.

The Wasps. Sceliphron caementarium (Drury) (Sphecinae: Sceliphrini) constructs individual cells of mud collected at the edges of ponds and streams. The nests are provisioned primarily with Araneidae, Thomisidae and Salticidae (Muma and Jeffers, 1945) and then sealed off with mud. Groups of contiguous cells are often covered by additional layers of mud and may appear as oval or oblong masses of up to 30 cells (see Muma and Jeffers, 1945 for plates of relevant mud-daubers and their nests). Trypoxylon politum Say (Larrinae: Trypoxylini) builds long, tubular nests from mud gathered at sites similar to those frequented by Sceliphron. The "pipe organ" nests usually contain between 3 and 5 cells, each provisioned with Araneidae of the genera Neoscona or Eustala (Muma and Jeffers, 1945; H. J. Brockmann, pers. comm.). Rather than constructing its own nest, the blue mud-dauber, Chalybion californicum (Saussure) (Sphecinae: Sceliphrini) either modifies and seals existing old cells of Sceliphron and Trypoxylon or cleans out and reprovisions recently completed cells. Dry mud from nearby nests is softened by mixing with water stored in the wasp's crop. The wet mud is then manipulated and used for sealing nests. Chalybion specializes in hunting small Theridiidae and Araneidae (Muma and Jeffers, 1945).

The Study Sites. Three sites in Alachua County, Florida were selected. Two were located in the Paynes Prairie State Preserve and were designated Boat House (BH) and Garage (G). Both sites had females of all three species actively building and provisioning nests. The boat house site had a $10 \mathrm{~m} \times 25 \mathrm{~m} \times 1 \mathrm{~m}$ high shaded crawl space with an unfinished pine ceiling, dirt floor and open sides. The 
structure was within $5 \mathrm{~m}$ of a lake and was surrounded on three sides by a lawn dotted with palms and turkey oak. A dense stand of palmetto and hardwoods was located ca. $100 \mathrm{~m}$ distant. The Garage site was located $150 \mathrm{~m}$ from the lake shoreline and was next to a small plot of palmetto-hardwood forest. Wasp nests covered the exterior walls of this painted wood structure and were exposed to ambient light. The third site, Rocky Creek (RC) was two cement bridge tunnels where State Road 121 crossed Rocky Creek. During the study, the water level was sufficiently low such that the sand bottom of the creek was exposed throughout most of the two tunnels. The tunnel entrances were fringed with tall grass, occasional shrubs and Eupatorium sp. Light levels inside the tunnels were the lowest among the 3 sites. The area surrounding the site was composed of cleared agricultural plots interspersed with thickets and small stands of oak and pine.

\section{RESULTS}

Table 1 lists the spiders observed at the 3 sites. Prey species are distinguished from non-prey species and web spiders from wandering spiders.

Web-Building Spiders. Eighty-three web spiders were collected, representing 12 genera in 4 families. Ten genera were taken as prey by the mud-daubers nesting at the study sites. Species of three genera of spiders were found living in open mud cells from which wasps had emerged earlier in the season. Males and females of Metazygia wittfeldae (McCook), Filistata hibernalis Hentz and Oecobius annulipes (Lucas) were removed from inside old nests of Sceliphron and Chalybion that were constructed over or close to seams and cracks in walls. Of 11 cells containing $M$. wittfeldae, 8 also contained egg cases. Two old cells with adult pairs and spiderlings inside were also noted. Genera of Araneidae and Theridiidae positioned webs either close to nesting sites (Argiope, Nephila, Micrathena and Neoscona) or within 10-15 cm of active nests (Leucauge, Tetragnatha, Tidarren, Latrodectus and Achaearanea). Webs of Argiope aurantia Lucas were found only at Rocky Creek, where the tall grass and bushes at the tunnel entrance afforded suitable habitat. The distribution of Micrathena sagittata (Walckenaer) appeared similarly limited by habitat, as webs were confined to the wood's edge behind the Garage site. 
Wandering Spiders. Five families were collected, totalling 43 spiders in 8 genera. Five of these genera are common prey items of mud-daubers. A Xysticus sp. was discovered inhabiting an inactive Sceliphron nest and a female Platycryptus undatus (De Geer) occupied a half-completed Sceliphron cell, constructed a retreat and positioned herself at the entrance. Species of Phidippus and Thiodina climbed over nests, but did not remain on these structures. However, species of Dolomedes were frequently noted on the outside of mud nests. They remained motionless for hours during the day and appeared to achieve an enhanced crypsis against the nest background.

Spider Size. Seventy-six specimens belonging to genera taken as prey by mud-daubers were collected at the 3 sites. Of these, only 9 exceeded the upper size range of congeners found paralyzed in wasp cells (Table 1). The 2 Argiope listed were also larger than conspecifics $(\mathrm{N}=3)$ that could not be handled (i.e., were repeatedly dropped after immobilization) by Sceliphron. These spiders were 15.0, 16.5, and $16.8 \mathrm{~mm}$ long respectively. Two spiders dropped by Chalybion were $15.3 \mathrm{~mm}$ [Pisaurina undulata (Keyserling)] and $14.6 \mathrm{~mm}$ long [Peucetia viridans (Hentz)]. The largest $P$. undulata provisioned by Chalybion was $11.8 \mathrm{~mm}(\mathrm{~N}=3)$, and the largest $P$. viridans was 13.8 $\mathrm{mm}(\mathrm{N}=14)$. Extensive data for Trypoxylon, generously provided by Dr. H. J. Brockmann, indicated that the heaviest of $289 \mathrm{Neo}-$ scona provisioned by Trypoxylon during June and July weighed 0.2400 grams. Spiders dropped by provisioning females exceed this weight on 12 occasions, ranging in weight from $0.2537-0.4236 \mathrm{~g}$. (Spiders were weighed to the nearest $0.1 \mathrm{mg}$.)

Wasp-Spider Interactions. Surprisingly, predation by mud-daubers on spiders living at nest sites was never observed. Brockmann (pers. comm.), who has spent over 3,000 hours observing wasps under bridges near Gainesville, has also never observed a single case of a wasp preying on a spider near the nesting site. Wasps repeatedly walked or flew within several centimeters of potential prey, displaying no observable taxes or predatory movements. In 2 separate incidents, female Sceliphron that had strayed into webs of Tidarren sisyphoides (Walckenaer) freed themselves after stinging the overly eager spider. In neither instance did the wasp show any further interest in the potential prey item, although in both cases the spider 


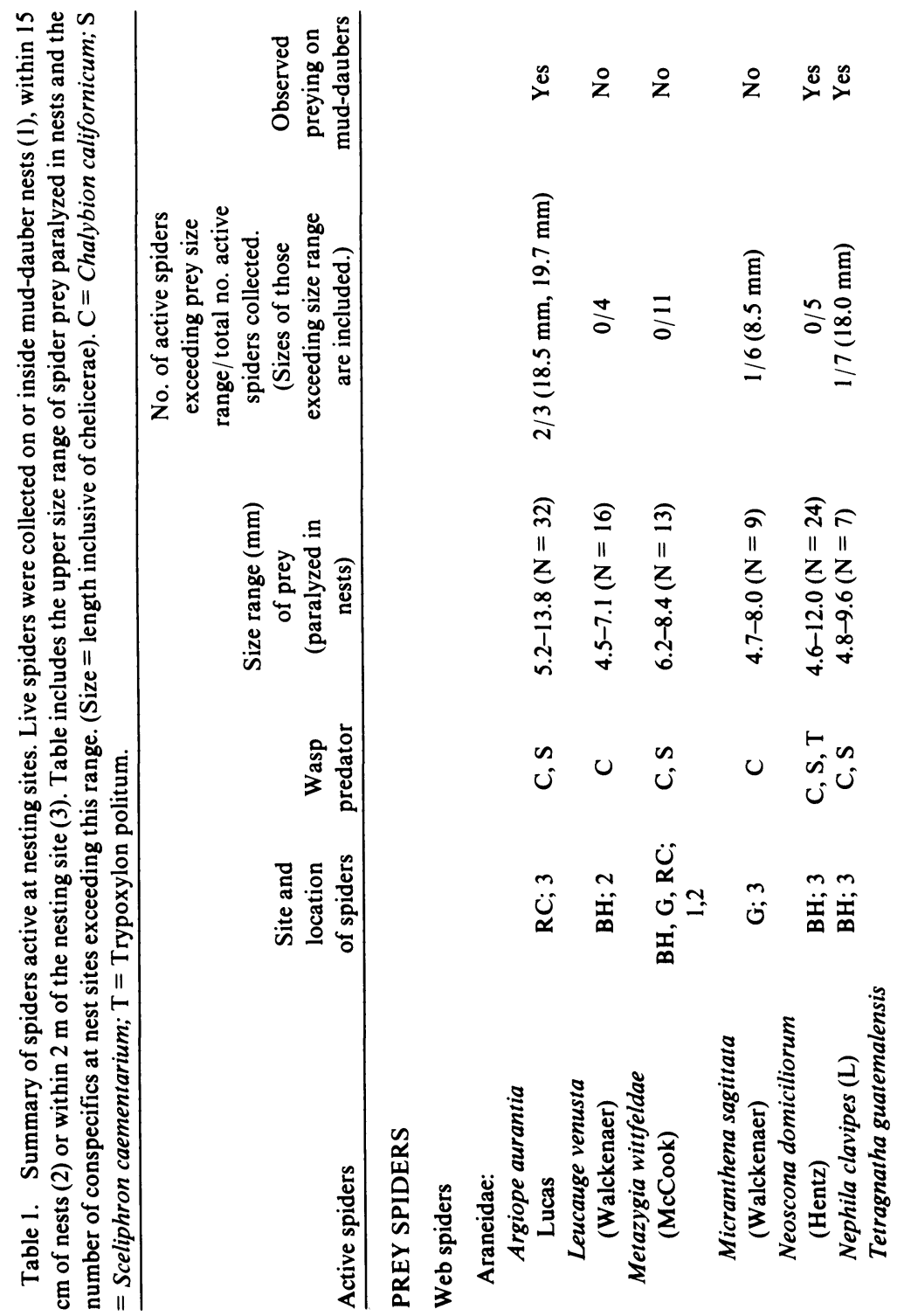




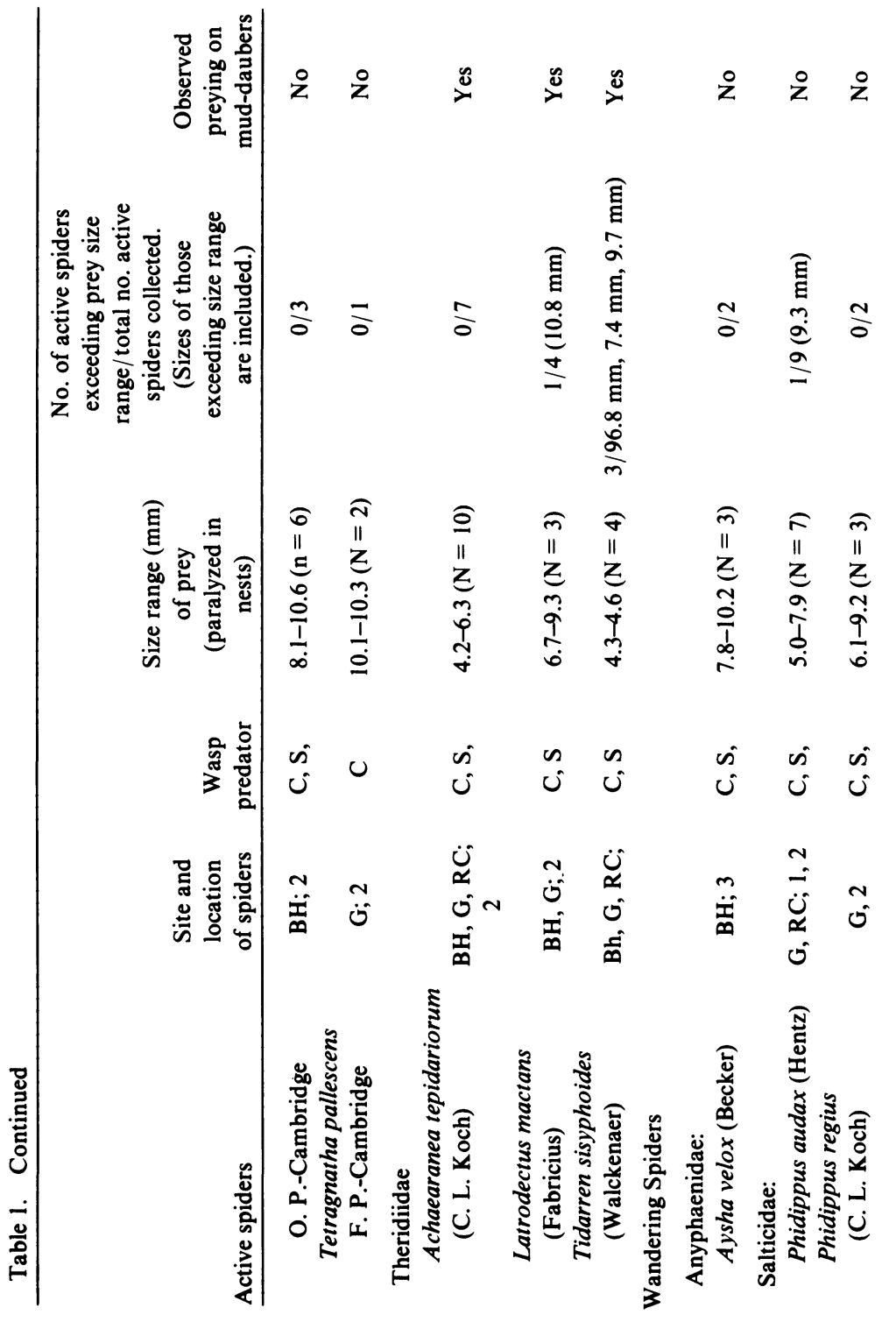




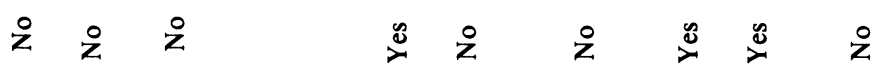

m

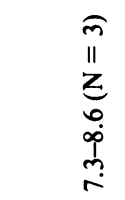

is is is

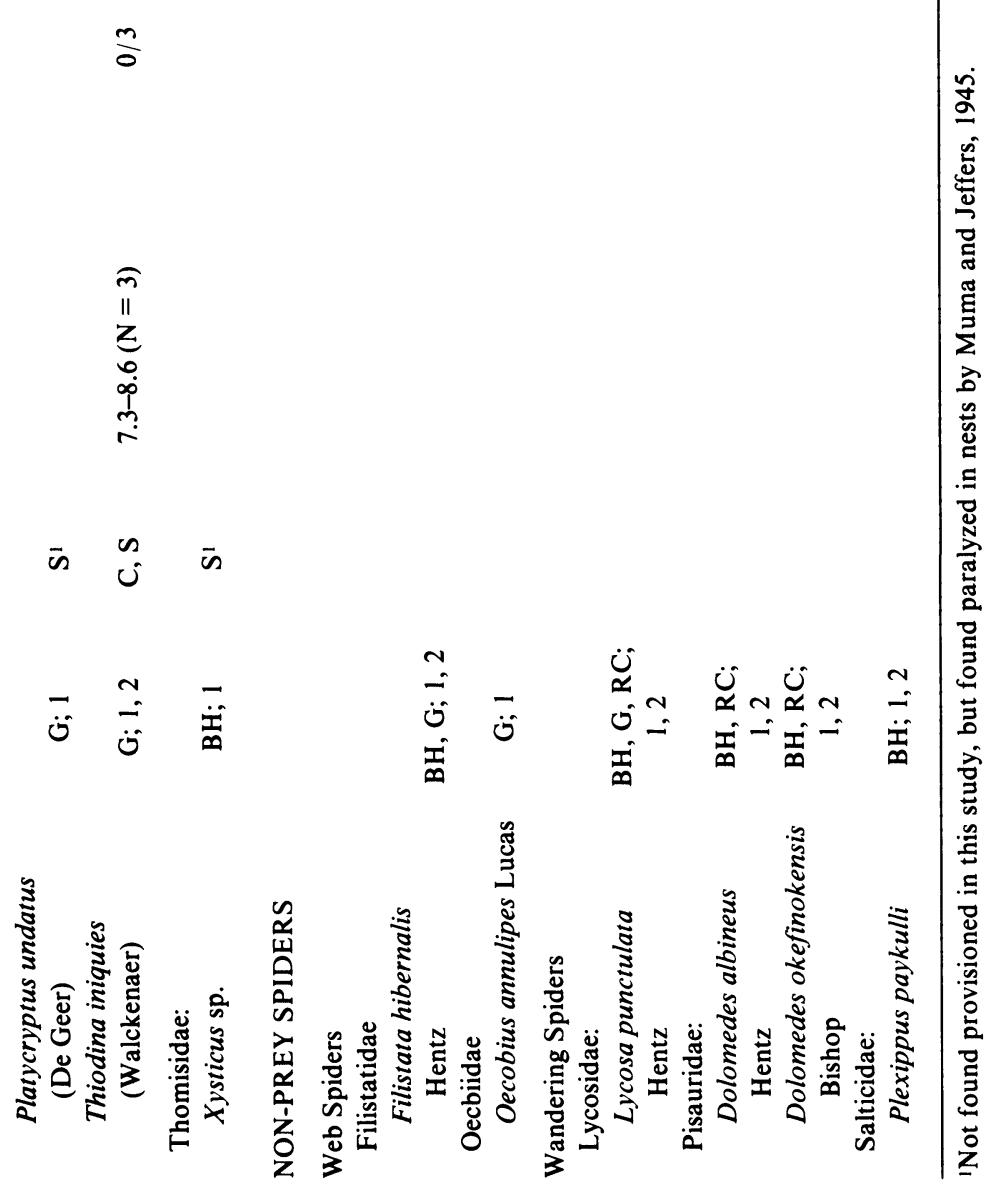


was paralyzed. Rather, after extricating themselves, both flew to nearby vegetation and groomed intensively before returning to their nests.

However, a number of spiders were observed preying on muddaubers. Wasps carrying very large prey or those having just left the nest sometimes blundered into webs situated directly in the flight path of the wasp. All 3 species of wasp were found entangled in webs of either Argiope aurantia, Neoscona domiciliorum (Hentz), Latrodectus mactans Fabricius, Tidarren sisyphoides, Nephila clavipes (Linnaeus), or Filistata hibernalis Hentz. Fourteen wasps were observed wrapped or trapped in webs. These included Trypoxylon (7), Sceliphron (5) and Chalybion (2). One of the Sceliphron noted was an emerging adult that was trapped in the sticky threads of $F$. hibernalis that covered its cell. Micrathena webs, positioned less than 0.5 meters off the ground, were too low to intercept wasps in flight. Smaller spiders such as $T$. sisyphoides and the smaller individuals of $L$. mactans and N.domiciliorum did not always attack wasps caught in webs. These spiders retreated out of the range of the struggling wasp on 5 occasions. Biting or wrapping were delayed until the wasp had exhausted itself and was quiescent. In contrast, two $A$. aurantia observed at Rocky Creek immediately descended from the hub, wrapped the prey, inflicted a "short bite" (Robinson, 1969) and then returned to the hub before further wrapping commenced. One Sceliphron and 3 Trypoxylon were dispatched in this manner. Predation on wasps by spiders is not restricted to webbuilders. Brockmann (pers. comm.) has observed attempted predation on mud-daubers by a Dolomedes sp. which leapt off a tunnel wall while attempting to grab a Trypoxylon hovering nearby. The spider was unsuccessful and pulled itself up the wall by the dragline. It is possible that large, mobile spiders of this type are preying on male Trypoxylon that sleep in the mud nests during the night.

\section{Discussion}

Barns, old houses, bridges and the vegetation surrounding them afford appropriate habitat for many groups of spiders. The muddaubing wasps are similarly attracted to such sites, for when water and mud are available, these sites provide favorable nesting substrate. It is not surprising therefore to observe spiders and spiderhunting wasps living in close proximity. It is noteworthy, however, 
when these spiders ( 76 of 107 collected in our study) are prey species of the nesting wasps, for it suggests that these spiders escape predation. This study addressed that question in particular.

Why Mud-Daubers Do Not Hunt at Nest Sites. The inability of mud-daubers to recognize and capture prey living amongst them poses interesting questions. As demonstrated by Tinbergen (1935) for the solitary wasp Philanthus triangulum (Fabricus), successful predation may involve the hierarchical sequencing of various "appetitive behaviors" (Craig, 1918), each controlled by a specific releasing stimulus. In Sceliphron, for example, visual releasers such as spider-sized objects on a contrasting background are known to release a predatory pounce from a wasp in flight (Eberhard, 1970), but it is highly probably that wasp search images vary between habitats. Conspecifics hunting in the canopy and those hunting in the leaf litter may respond to learned visual cues appropriate to the particular microhabitat being searched. It is possible then that muddaubers were catching spiders against backgrounds different from those presented to them at the 3 study sites. This might explain in a proximate sense why we observed no wasps attacking spiders at these sites. One might also propose that mud-daubers require a minimum light level to activate particular behaviors of the predatory sequence. However, nests at the Garage site were not in shade, and no hunting by wasps was observed. Are spiders at nest sites too large for mud daubers to immobilize and provision? The data strongly suggest otherwise, as less than $12 \%$ of potential prey collected during the study exceeded the upper range of spiders found paralyzed in wasp nests (Table 1).

One ultimate explanation of why "leave the nest site" appears to be a behavioral rule for foraging mud-daubers posits the importance of spider predation on wasps. Spiders that have previously encountered a wasp may be more likely to successfully defend themselves from subsequent wasp attack, and the probability of attacking a spider that has previously encountered and successfully handled a wasp may be greater close to or at nest sites than it is at a distance from such sites. Moreover, it is possible that spiders may learn to recognize characteristic vibrational signatures of mud-daubers. Such pretactile prey determination has been hypothesized (Robinson and Mirick, 1971), although Suter (1978) could not identify such a mechanism in the araneid Cyclosa turbinata (Walckenaer). 
It is also possible that by not hunting at nest sites, mud-daubers more effectivley conceal the location of their nest. Such a mechanism has been proposed to explain why raptors usually do not hunt near their own nests (Durango, 1949). Mud-dauber larvae fall prey to a variety of parasitoids and inquilines ( $R a u$ and $R a u, 1916$; Krombein, 1967). Hunting away from the nest site can reduce the probability of parasitization if the following assumptions are met: (1) The parasite encounters the host species at sites where the host species hunts; (2) The parasite trails the host species back to the nest; (3) The host species can evade the trailing parasite, the probability of so doing increasing with the distance over which the host species is trailed.

Certain host-parasite systems involving mud daubers and sarcophagid flies meet the above assumptions. Flies in the tribe Miltogrammini are larviporous parasites of many aculeates, including sphecid wasps (Allen, 1926). The genera Amobia and Senotainia include species of mud-dauber parasites that follow prey-laden wasps to their nests (Chapman, 1959; Cole, 1969). The adult flies are nectivorous, and it is likely that they encounter foraging wasps on vegetation. Prey-laden mud daubers often fly at reduced speeds, and their maneuverability is similarly impaired (Obin, pers. obs.). They are presumably easier to follow at such times. Furthermore, a wasp with prey assures a trailing fly that the wasp is nesting, that a cell is being provisioned and is consequently open, and that there will be food available in that cell. Sarcophagid flies have been observed trailing $C$. californicum females to their mud nests over distances of 3-5 $\mathrm{m}$. The pursued wasps often took circuitous routes to their nests, and in certain instances left the site altogether before reaching their nest (Obin, unpublished data). Whether such behavior results in successful evasion is not known, but it does suggest that wasps may require flight distances greater than those observed in order to evade trailing Miltogrammini. If so, selection may, on average, favor wasps that do not hunt close to their nest.

Interactions between spiders and mud-daubers may not be exclusively antagonistic, and the selective advantage accruing to wasps that do not hunt at nest sites may be a consequence of a site-specific mutualism between these two traditional enemies. During the study, various parasites of mud-daubers were observed in webs at nest sites. These included bombyliid and sarcophagid flies as well as 
chrysidid and mutillid wasps. These observations suggest that spider predation may reduce the parasite load at mud-dauber nest sites. Since mud-daubers are usually adept at recognizing and maneuvering on webs and retreats (Eberhard, 1970; Coville, 1976), spiders at nest sites may pose only a limited threat to wasps. We have observed individuals of all three species of wasp successfully nidify and provision nests positioned such that the wasp flew through or walked behind a web on each trip to and from the nest. Wasps became entangled in webs when their regular flight path was disrupted during agonistic encounters or when they attempted to provision very large spiders. Empirical evaluation of the relative costs (e.g., probability of predation, costs associated with increased flight distance to foraging patches) and benefits (reduced parasitism) of hunting away from the nest site is in progress. One predication of the "reduced parasitism" hypothesis is that a small percentage of mud daubers at any site may "cheat"-i.e., may occasionally prey on spiders at nest sites. Relative to other wasps in the population, these wasps would enjoy reductions in the time and energy costs of hunting and transporting prey, while at the same time benefitting from the "parasite umbrella" afforded by spiders active at nest sites. The relative frequencies of cheating and non-cheating (hunting away from nest sites) may perhaps be maintained by frequencydependent selection (Fisher, 1930) in an Evolutionarily Stable Strategy (Maynard Smith and Price, 1973).

The Effects of Prey Size and Availability on Mud-Daubers. Various authors have suggested that spider size constrains prey collection by Chalybion (Muma and Jeffers, 1945), Sceliphron (Muma and Jeffers, 1945; Eberhard, 1970) and Trypoxylon (Cross et al., 1975). Selection should favor wasps that minimize both the risks and metabolic cost of (1) immobilizing and (2) transporting large spiders. Do wasps refrain from attacking large prey that they can incapacitate but not readily transport, or is the upper range of prey size found in nests a reflection of the wasp's inability or reluctance to paralyze prey above a certain size? Measurements of spiders dropped by provisioning mud daubers indicate that the wasps successfully incapacitate spiders that exceed the upper range of prey size noted in nests, but fail in their ability to transport or cache them. 
The data differ from those of Muma and Jeffers regarding prey selection by Chalybion and Sceliphron. In their study in Maryland, the theridiid Latrodectus mactans constituted $25 \%$ of all prey taken by Chalybion. Locally, L. mactans is provisioned less frequently, comprising less than $5 \%$ of all prey taken. These differences may be due in part to the availability of more prey species in Florida. Spiders not found in Maryland nests but taken by Chalybion and Sceliphron in Florida include Tetragnatha guatemalensis O. P.Cambridge, Tetragnatha pallescens F. P.-Cambridge, Pisaurina undulata, Mecynogea lemniscata (Walckenaer), Gasteracantha cancriformis (Linnaeus), and Tidarren sisyphoides. M. lemniscata and G. cancriformis were also found provisioned in Sceliphron cells. Maryland constitutes the northern most distribution for M. lemniscata (Kaston, 1978). G. cancriformis ranges only as far north as North Carolina (Levi, 1978). The distribution of T. sisyphoides in North America is restricted to the southern United States and Mexico (Levi, 1955).

Nest Sites as Spider Habitat. Mud-dauber nest sites may be particularly good habitats for some spiders. Benefits to spiders at such sites include the following:

1. Mud nests afford environmentally buffered refugia and brood chambers and may provide cryptic backgrounds.

2. Additional prey is available, including the wasps themselves, other spiders (Tolbert, 1975), mites and hymenopterous and dipterous parasites of mud-daubers, "renting" Arthropods that use empty mud-dauber cells (Dermaptera, lepidopterous larvae and non-sphecid wasps) and nest associates such as Psocoptera.

3. The risk of predation from wasps nesting at these sites is reduced.

Although somewhat counter-intuitive, the probability of wasp predation appears to be lower for spiders living at sites where wasps nest. The greatest threat may exist for smaller, naive individuals, and a small cost is probably incurred by those spiders whose web is damaged after intercepting a wasp. However, the benefits of living amidst mud-daubers may outweigh these potential costs. Associations of predator and prey at predator nests sites are not without precedent. Nesting of passerines with raptors has been reported 
(Durango, 1949; McGillivray, 1978; Parker, 1981). Since raptors hunt away from their nests, traditional prey species nesting close by appear less threatened (Brown and Amadon, 1968; Parker, 1981).

\section{ACKNOWLEDGMENTS}

The author wishes to thank Dr. H. Jane Brockmann for review of the manuscript and Jeff Lucas for advice and suggestions. G. B. Edwards and Jon Kochalka offered invaluable assistance identifying problematic specimens. An anonymous reviewer suggested consulting the avian literature. Special thanks are due the Florida Department of Natural Resources and the rangers at the Paynes Prairie State Preserve.

\section{Literature Cited}

Allen, H. W.

1926. North American species of two-winged flies belonging to the tribe miltogrammini. U.S. Natl. Mus. Proc., 68(9): 1-106.

Brown, L., AND D. Amadon.

1968. Eagles, hawks and falcons of the world. McGraw-Hill, New York.

Chapman, R. F.

1959. Some observations on Pachyopthalmus africa Curran, a parasite of Eumenes macillosus De Geer. Proc. Roy. Entomol. Soc. London, 34: $1-6$.

Coville, R. E.

1976. Predatory behavior of the spider wasp Chalybion californicum (Hymenoptera: Sphecidae). The Pan-pacific Entomologist, 52: 229-233.

Cole, F.

1969. The flies of western North America. University of California Press, Berkeley.

Craig, W.

1918. Appetites and aversions as constitutents of instincts. Biol. Bull., 34: 91-107.

Cross, E. A., M. G. Smith, and T. R. Bauman.

1975. Bionomics of the organ-pipe mud-dauber, Trypoxylong politum (Hymenoptera: Sphecidae). Ann. Ent. Soc. Amer., 68: 901-916.

DORRIS, P. R.

1970. Spiders collected from mud-dauber nests in Mississippi. J. Kans. Ent. Soc., 43(1): 10-11.

Durango, $\mathrm{S}$.

1949. The nesting associations of birds with social insects and with birds of different species. Ibis, 91: 140-143. 
EberhaRd, W.

1970. The predatory behavior of two wasps, Agenoideus humilis (Pompilidae) and Sceliphron caementariuim (Sphecidae) on the orb-weaving spider, Araneus cornutus (Araneidae). Psyche, 77(2): 243-251.

FISHER, R. A.

1930. The Genetical Theory of Natural Selection. Claredon Press, Oxford.

KaSTON, B. J.

1978. How To Know The Spiders. Third Edition. Wm. C. Brown and Company. Dubuque, lowa.

Krombein, $\mathbf{K}$.

1967. Trap-nesting wasps and bees. Life histories, nests and associates. Smithsonian Press. Washington, D.C.

LEVI, H. W.

1955. The spider genera Chrysso and Tidarren in America (Araneae: Theridiidae). J. New York Ent. Soc., LXIII. 59-81.

1978. The American orb-weaver genera Colphepeira, Micrathena, and Gasteracantha north of Mexico (Araneae, Araneidae). Bull. Mus. Comp. Zool., 148(9): 417-422.

Maynard Smith, J. and G. R. Price.

1973. The logic of animal conflicts. Nature, 246: 15-18.

McGillivray, W. B.

1978. House Sparrows nesting near a Swainson's Hawk Nest. Can. Field-Nat., 92: 202-203.

Muma, M. H., AND W. F. JefFers.

1970. Studies of the spider prey of several mud-dauber wasps. Ann. Ent. Soc. Amer., 38: 245-255.

PARKer, J. W.

1981. Nest Associates of the Mississippi Kite. J. Field Ornithol., 52(2): 144-145.

Peckham, G. W., and E. G. Peckham.

1898. Instincts and habits of the solitary wasps. Bull. Wisc. Geol. and Nat. Hist. Survey, 2, Sci. Ser. 1: 176.

RAU, P.

1935. The spider prey of the mud wasp. Sceliphron caementarium (Aranea, Hymen.: Sphecidae). Ent. News, 46: 267-270.

RAU, P., AND N. RAU

1916. The biology of the mud-daubing wasps as revealed by the contents of their nests. Journ. Anim. Behavior, 6: 27-63.

RoBinson, M. H.

1969. Predatory behavior of Argiope argentata (Fabricius). Am. Zool., 9: 161-173.

Robinson, M. H., AND H. MiRick.

1971. The predatory behavior of the golden web spider, Nephila clavipes (Araneae: Araneidae). Psyche, 78: 123-139.

SUTER, R. B.

1978. Cyclosa turbinata (Aranea, Araneidae): Prey discrimination via webborne vibrations. Behav. Ecol. Sociobiol., 3: 283-296. 


\section{Tinbergen, $\mathbf{N}$.}

1935. Über die Orientierung des Bienenwolfes (Philanthus triangulum (Fabr.)) II. Die Dienenjagd', Zs. vergl. Physiol., 21: 699-716.

TOLBERT, W. W.

1975. Predator avoidance behaviors and web defensive structures in the orb weavers Argiope argentata and Argiope trifasciata (Araneae: Araneidae). Psyche, 82: 29-52. 

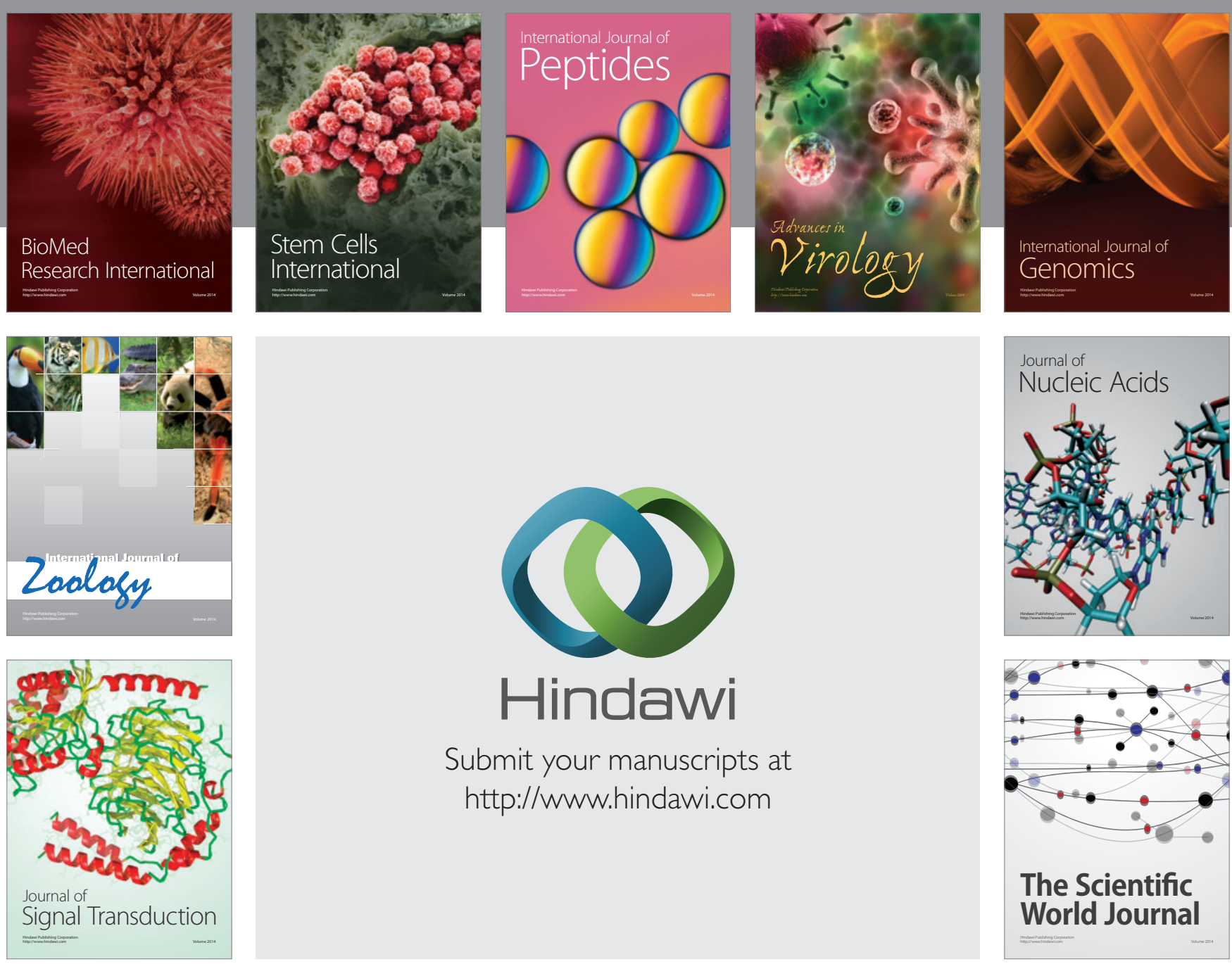

Submit your manuscripts at

http://www.hindawi.com
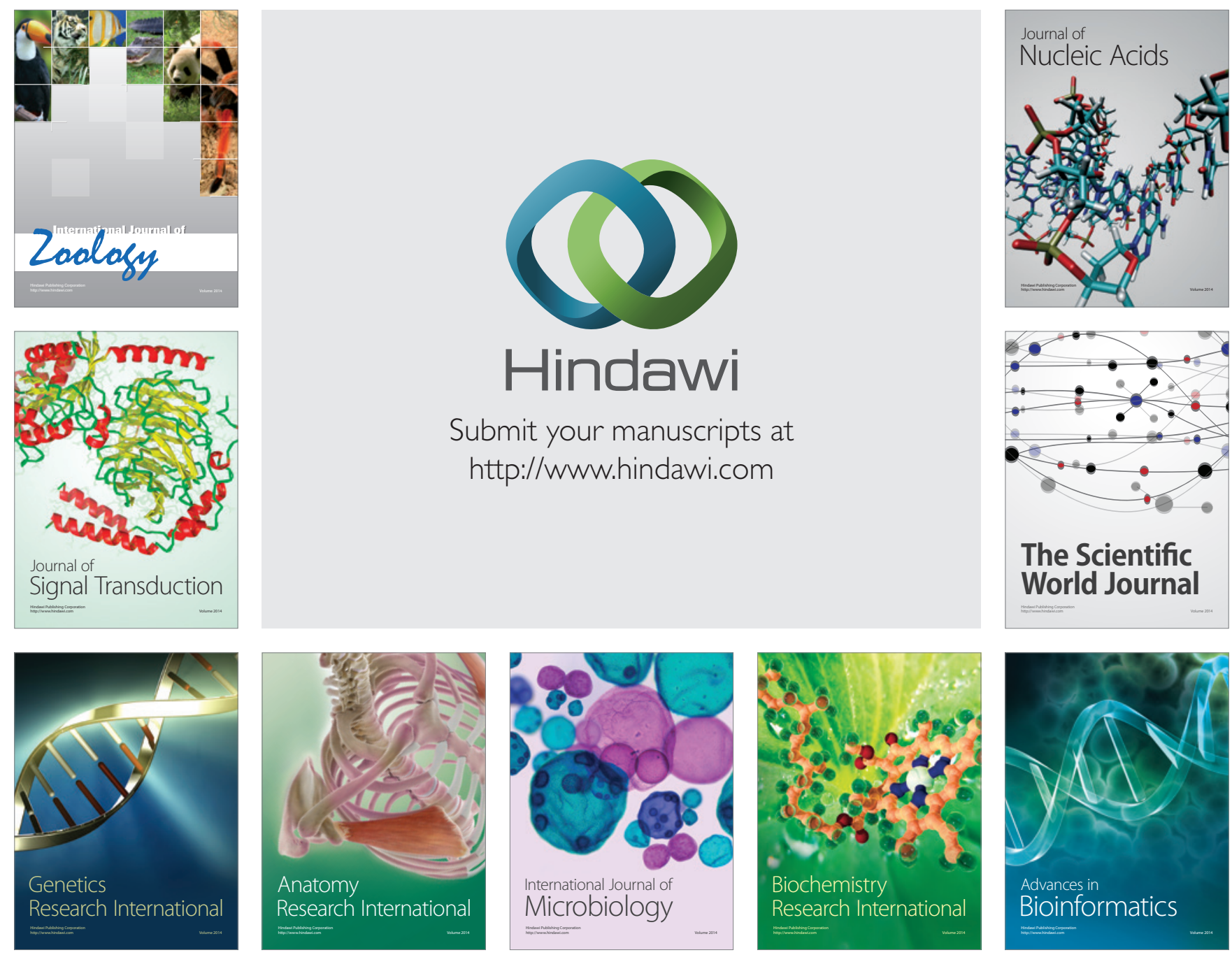

The Scientific World Journal
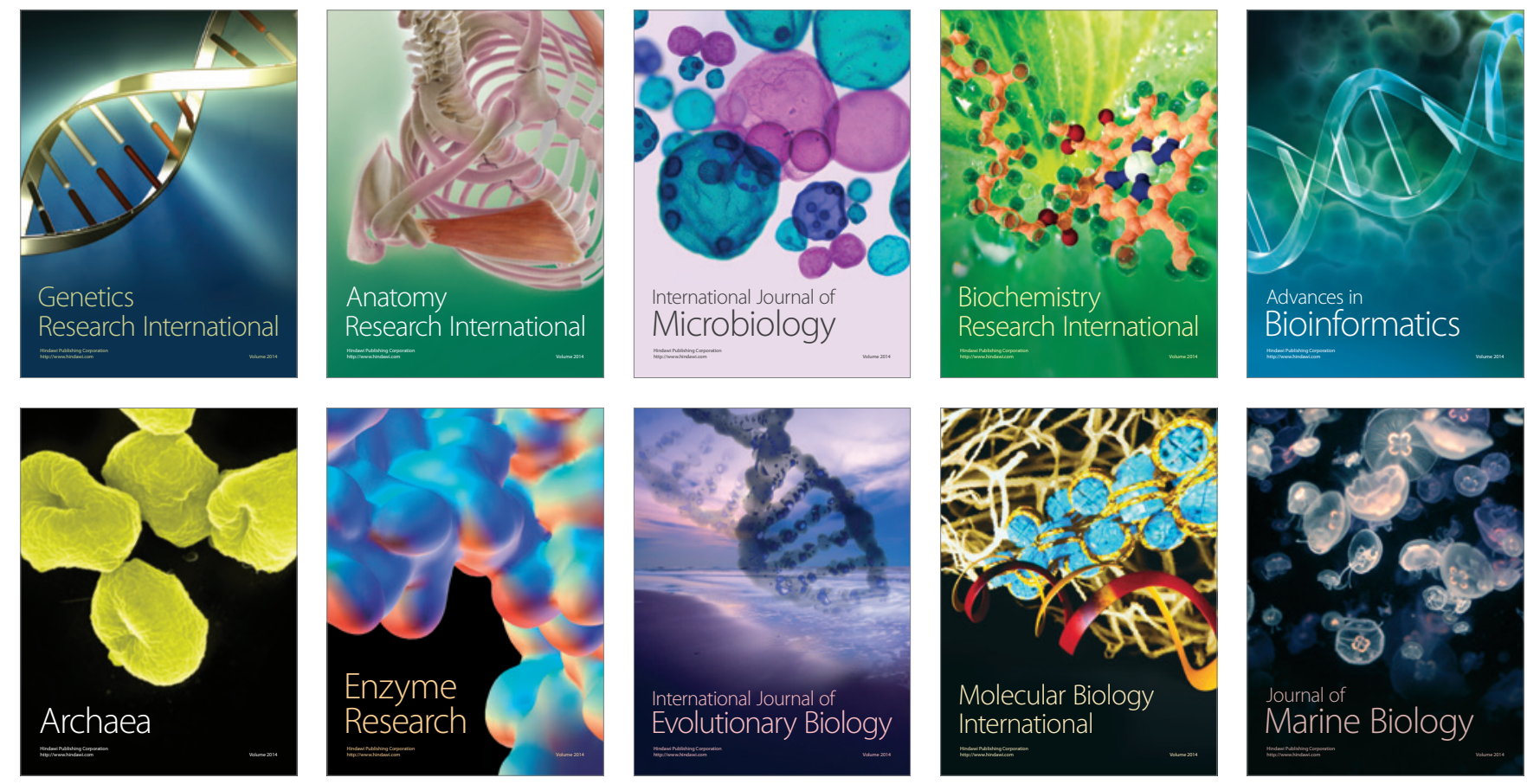